\title{
36. ORIGIN AND SIGNIFICANCE OF LATE PLIOCENE PHOSPHATIC HARDGROUNDS ON THE QUEENSLAND PLATEAU, NORTHEASTERN AUSTRALIAN MARGIN ${ }^{1}$
}

\author{
Craig R. Glenn ${ }^{2}$ and John D. Kronen, Jr. ${ }^{2}$
}

\begin{abstract}
Late Pliocene hardgrounds emplaced on the Queensland Plateau between 3.45 and 3.0 Ma record an episode of drastically reduced sedimentation and the development of a complex assemblage of diagenetic and authigenic minerals. Reduced sedimentation rates associated with the hardgrounds $(\sim 2 \mathrm{~m} / \mathrm{m}$. y.) are thought to stem from current winnowing and erosion and backstepping of shallow-water carbonates in response to drowning of the plateau during this time interval. The timing of hiatus and hardground development appears to correlate with increases in global oceanic current activity accompanying late Pliocene ice age transitions. The mineral assemblage of this horizon includes authigenic carbonate fluorapatite, ferroan and nonferroan dolomites, sparry calcites, and botryoidal and laminated mixtures of iron oxides and carbonate fluorapatite. Carbonate fluorapatites and dolomites form both void-filling and replacement cements. Both precipitation of carbonate fluorapatite and dissolution of aragonite in the hardgrounds are suggested to be related to a coincidence of a mid-water aragonite lysocline and the oxygen minimum zone. The rise of the aragonite lysocline at this time is supported by a coeval rise in the calcite compensation depth in the equatorial Pacific Ocean. The intimate co-occurrences of iron oxides and carbonate fluorapatite layers are suggested to result from an oxidationreduction-controlled iron-pumping mechanism that delivers sorbed phosphorus to reducing or suboxic sites where carbonate fluorapatite has been precipitated. The dissolution of aragonite and the subsequent precipitation of sparry calcites in these sediments originated in an open marine setting. They are not the result of freshwater incursion.
\end{abstract}

\section{INTRODUCTION}

Most marine sedimentary phosphate deposits are associated with organic-rich strata and siliceous sediments and with the sediments of highly productive upwelling zones. The modern phosphatic deposits of the Peru/Chile margin (Glenn and Arthur, 1988; Garrison and Kastner, 1990) and off the Pacific coast of Mexico (Jahnke et al., 1983) are examples. In these settings, upwelling provides a continuous supply of nutrients to the surface waters that results in (1) high primary productivity, (2) high organic carbon and phosphate fluxes into the sediments, and (3) the formation and maintenance of suboxic to anoxic sediments. However, modern continental margin phosphate-rich deposits also are currently forming in areas having little coastal upwelling and low productivity, such as those found off eastern Australia (cf. Kress and Veeh, 1980; Heggie et al., 1990). These Pleistocene to Holocene deposits have formed where upwelling is weak or absent and fluxes of organic carbon and organic phosphate to the sediments are low. In 1950, exploration of mid-Pacific Ocean seamounts discovered rocks that contained phosphatized limestone, apparently phosphatized by bird guano (e.g., Hamilton, 1956). Further exploration found that phosphorite deposits were common on seamounts throughout the world's oceans and occurred on relatively isolated submerged seamounts, plateaus, ridges, and other elevated portions of the seafloor (see Burnett et al., 1987, for review). Such insular phosphorites typically are coated with iron-manganese crusts (Burnett et al., 1987). Their mineralogy and major element geochemistry are similar to those of continental margin "upwelling" deposits, although they are characterized by very low concentrations of organic carbon and uranium and an absence of pyrite sulfur. These insular phosphorites are closely associated with iron-manganese nodules and crusts, are believed to be submarine in origin and linked to the oxygen minimum zone (e.g., Halbach et al., 1982), and are characterized by low sedimentation rates (e.g., De Carlo and Fraley, 1992). The presence of phosphorites in both nonupwelling and upwelling environments seems to indicate that

\footnotetext{
${ }^{1}$ McKenzie, J.A., Davies, P.J., Palmer-Julson, A., et al., 1993. Proc. ODP, Sci. Results, 133: College Station, TX (Ocean Drilling Program).

${ }^{2}$ Department of Geology and Geophysics, School of Ocean and Earth Science and Technology, University of Hawaii, Honolulu, HI 96822, U.S.A.
}

different processes operate to control the supply and concentration of phosphate, fluoride, and other elements in the sediments during the precipitation and formation of phosphate-rich nodules and crusts.

This paper discusses the nature and mode of origin of phosphatic hardgrounds recovered during Leg 133 on the Queensland Plateau. Phosphatic and related iron oxide components were found in predominantly carbonate hardground sediments recovered from Sites 812 through 814 west of Tegrosse Reef on the southwestern margin of the Queensland Plateau, off the Great Barrier Reef of northeastern Australia. These three sites represent a transect across the southwestern margin of the Queensland Plateau (QLP), marking a relative increase in water depth (WD) from Site $812(462 \mathrm{~m})$ to Site $814(520$ $\mathrm{m})$ to Site $813(539 \mathrm{~m})$. Drilling at Site 812 penetrated a 300 -m-thick sequence of carbonate-rich platform top sediments that range in age from middle Miocene to Pleistocene. Micropaleontological data (Katz and Miller, 1991; Katz et al., this volume) indicate subsidence and deepening of the depositional environment from outer neritic $(0-200 \mathrm{~m})$ during the late Miocene to early Pliocene through upper bathyal $(200-600 \mathrm{~m})$ during the late Pliocene and Pleistocene. At Sites 812,813 , and 814 , this paleowater depth transition occurs within a cored interval of only a few meters and is marked on the interior portion of the QLP by an almost 1-m-thick phosphatic nodular and encrusted hardground recovered between about 26 and $28 \mathrm{mbsf}$ at Site 812 , and at 57 and 58 mbsf at Site 814 (Fig. 1). This approximately 1 -m-thick layer resides between foraminifer and calcareous nannofossil datums at 3.0 and $3.45 \mathrm{Ma}$, respectively (Fig. 1). Net sedimentation rates in this interval are thus about $2 \mathrm{~m} / \mathrm{m}$.y. Along the outer edge of the plateau, at Site 813 , these hardground layers were not encountered but are instead replaced between the 3.0 and 3.45 datums with a unit of nannofossil foraminiferal ooze (64.2-82.8 mbsf) containing pink iron- or manganese-stained foraminifers. This unit has, at its base (76.7-82.8 mbsf), minor proportions of reworked phosphatic and dolomitic lithoclasts (determined by X-ray diffraction), replaced foraminifers, and ferruginized grains, all presumably reworked from the shallower hardground surfaces (Fig. 1). In addition, this unit lies on a significant hiatus present between nannofossil datums 3.45 and $3.51 \mathrm{Ma}$ (Fig. 1). As outlined below, the formation of this hardground and the sands derived from it occurred during an extended interval of very slow sedimentation, nondeposition, bio- 


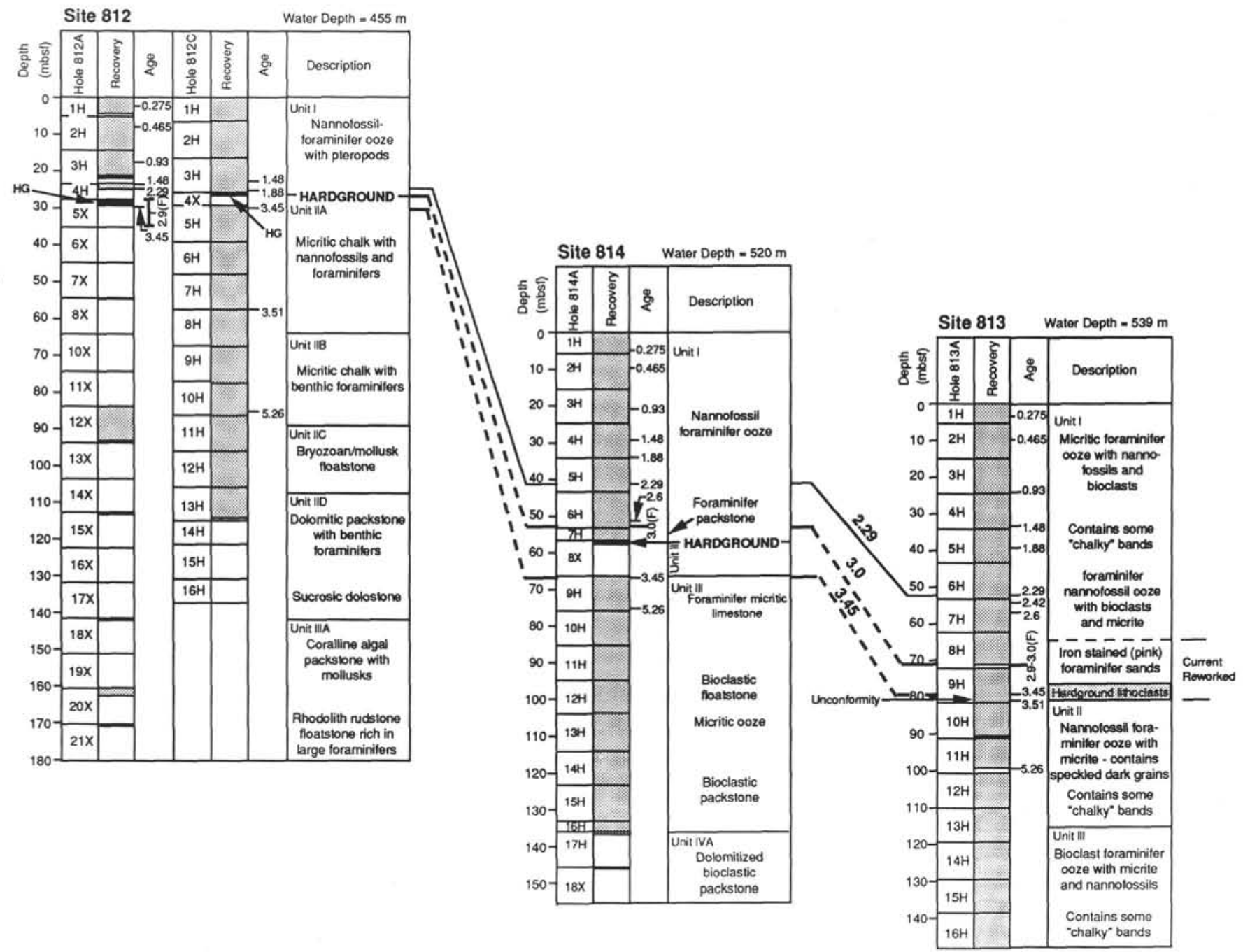

Figure 1. Correlation section of Sites 812,814 , and 813 of the Queensland Plateau transect, showing lithologic and age data. Note increased sequence condensation toward shallower water depths. Reworked portions of the 3.0-3.45 Ma hardground occur at Site 813. Nannofossil ages from Gartner et al. (this volume), planktonic foraminifer ages (F) from Kroon et al. (this volume). Ages in Ma.

erosion, submarine erosion, and winnowing, processes presumably reflecting increased current activity that affected the margin and accompanying the late Pliocene glacial transition at about $3 \mathrm{Ma}$. We suggest that the deepening of the margin caused backstepping of the locus of shallow-water sediment deposition and, therefore, starved this area of shallow-water bioclastic sediments during these times. This deepening also appears to coincide with a rapid eustatic rise of sea level and the formation of condensed sections elsewhere at about 3.4 Ma (cf. Haq et al., 1988). Mineralogies and lithologies of these hardgrounds were determined by petrographic, X-ray diffraction (XRD), electron microprobe (EMP; Table 1), energy dispersive X-ray fluorescence spectrometry (EDS), and cathodoluminescence (CL) analyses. Below, we discuss the petrographic and geochemical characteristics of these deposits and the significance of their origin.

\section{PETROLOGY AND GEOCHEMISTRY}

\section{Phosphatic Constituents}

The hardgrounds encountered at Sites 812 and 814 (Figs. 2, 3, and 4) define an abrupt contact with their overlying sediments (Fig. 4A). They exist as well-defined phosphatic and goethitic hard layers on their upper surface that gradually grade downward through well-indurated to poorly indurated, dolomitized, bioclast-bearing, foraminiferal bio- micrites over a span of about $1 \mathrm{~m}$. Porosity is usually moldic with minor interparticle voids. Infilled large borings up to $3 \mathrm{~cm}$ in diameter that penetrate the hardground layer (Fig. 3B) indicate the formation of a well-lithified substrate before the deposition of overlying units. The uppermost portion of the hardground contains phosphatic nodules about $3 \mathrm{~cm}$ in diameter (Figs. 2 and 4 ) bound by phosphatic, calcitic, and ferroan dolomitic cements and is encrusted with botryoidal and laminated layers of intermixed phosphatic cements and iron oxides. As in most other marine phosphorites, the phosphatic mineral occurring in the deposits is carbonate fluorapatite (CFA).

Although the lithified and encrusted sedimentary unit designated as a hardground is up to $1 \mathrm{~m}$ thick, the uppermost $10 \mathrm{~cm}$ of nodular and encrusted material is the most lithologically complex and significant. Figure 2 shows the top surface hardground sample recovered at Hole $812 \mathrm{C}$. The sample has a nodular core of lithified wackestone to packstone that is surrounded by multiple subsequent generations of foraminiferal wackestone and packstone layers, each individually cemented by CFA and/or dolomite, and then an outermost crust of laminated CFA and goethite cement. The seafloor was most likely composed of a blanket of nodules (probably up to $10 \mathrm{~cm}$ in diameter) bound together by a complex layering of episodically and slowly deposited, winnowed, eroded, and cemented sediments, capped by a red-brown crust of CFA and goethite cement. Epifaunal boring (Figs. 
Table 1. Electron microprobe results from Queensland Plateau hardgrounds.

\begin{tabular}{|c|c|c|c|c|c|c|c|c|c|c|c|c|c|}
\hline PT No. & Description & $\mathrm{Na}_{2} \mathrm{O}$ & $\mathrm{MgO}$ & $\mathrm{Al}_{2} \mathrm{O}_{3}$ & $\mathrm{SiO}_{2}$ & $\mathrm{P}_{2} \mathrm{O}_{5}$ & S & $\mathrm{K}_{2} \mathrm{O}$ & $\mathrm{CaO}$ & $\mathrm{MnO}$ & $\mathrm{Fe}_{2} \mathrm{O}_{3}{ }^{4}$ & Sum & Mineralogy \\
\hline 1 & Red laminae of phosphatic goethite. & 0.58 & 0.79 & 1.70 & 0.93 & 18.33 & 0.95 & 0.02 & 38.44 & 0.51 & 18.27 & 80.52 & 1) CFA. 2) Fe oxides \\
\hline 2 & Light amber phosphatic carbonate laminae. & 0.58 & 0.86 & 0.67 & 0.55 & 25.03 & 0.83 & 0.05 & 48.61 & 0.12 & 2.25 & 79.53 & 1) $\mathrm{CFA}$ \\
\hline 2 & Red laminae of phosphatic goethite. & 0.04 & 3.70 & 6.31 & 2.12 & 2.04 & 0.09 & 0.02 & 8.33 & 1.45 & 62.29 & 86.40 & 1) CFA. 2) Fe oxides \\
\hline 3 & Light amber phosphatic carbonate laminae. & 0.73 & 0.68 & 0.77 & 0.20 & 26.21 & 1.21 & 0.01 & 51.34 & 0.26 & 5.11 & 86.53 & 1) $\mathrm{CFA}$ \\
\hline 4 & Light gray-amber phosphatic carbonate. & 0.67 & 0.66 & 0.82 & 0.36 & 23.82 & 1.31 & 0.03 & 47.71 & 0.42 & 7.46 & 83.26 & 1) $\mathrm{CFA}$ \\
\hline 5 & Amber-red laminae of phosphatic goethite. & 0.06 & 3.53 & 4.63 & 2.29 & 2.86 & 0.09 & 0.01 & 4.99 & 0.15 & 62.52 & 81.14 & 1) CFA, 2) Fe oxides \\
\hline 5 & Red laminae of phosphatic goethite. & 0.35 & 2.64 & 2.34 & 1.50 & 9.31 & 0.25 & 0.01 & 16.86 & 0.08 & 46.52 & 79.86 & 1) CFA. 2) Fe oxides \\
\hline 6 & Amber-red laminae of phosphatic goethite. & 0.45 & 1.81 & 1.67 & 0.88 & 17.71 & 0.76 & 0.01 & 31.42 & 0.05 & 29.73 & 84.50 & 1) $\mathrm{CFA}$, 2) Fe oxides \\
\hline 6 & Red laminae of phosphatic goethite. & 0.53 & 1.66 & 1.38 & 0.90 & 17.13 & 0.45 & 0.04 & 31.03 & 0.03 & 27,12 & 80.26 & 1) CFA. 2) Fe oxides \\
\hline 7 & Amber-red laminae of phosphatic goethite. & 0.26 & 2.85 & 5.16 & 1.24 & 8.75 & 0.51 & 0.01 & 16.16 & 0.02 & 42.18 & 77.14 & 1) CFA. 2) Fe oxides \\
\hline 7 & Red laminae of phosphatic goethite. & 0.02 & 3.03 & 5.31 & 1.16 & 1.95 & 0.38 & 0.02 & 17.33 & 0.05 & 44.02 & 73.29 & 1) CFA. 2) Fe oxides \\
\hline 8 & Micritic matrix. & 0.07 & 1.57 & 0.07 & 0.07 & 0.26 & 0.10 & 0.01 & 59.23 & 0.06 & 0.19 & 61.63 & 1) $\mathrm{Mg}$ calcite \\
\hline 9 & Dark brown matrix above CFA cement. & 0.02 & 2.31 & 5.18 & 0.87 & 1.40 & 0.18 & 0.01 & 7.83 & 0.16 & 41.57 & 59.52 & 1) Fe oxides. 2) CFA \\
\hline 10 & Upper seam of CFA cement veneer. & 0.65 & 0.80 & 0.11 & 0.05 & 28.53 & 1.89 & 0.01 & 51.63 & 0.03 & 0.57 & 84.26 & 1) CFA \\
\hline 10 & Lower seam of CFA cement veneer. & 0.79 & 0.85 & 0.12 & 0.05 & 26.77 & 1.57 & 0.01 & 50.26 & 0.04 & 0.47 & 80.91 & 1) $\mathrm{CFA}$ \\
\hline 11 & Dark matrix above leak in cement seam. & 0.84 & 1.61 & 1.39 & 0.29 & 21.34 & 0.40 & 0.00 & 40.10 & 0.10 & 9.81 & 75.88 & 1) CFA. 2) Dolomite. 3) Fe oxides \\
\hline 12 & Inside of amber-stained foraminifera test. & 0.13 & 4.72 & 6.51 & 1.11 & 5.24 & 0.05 & 0.01 & 11.06 & 0.08 & 49.29 & 78.19 & 1) Fe oxides. 2) CFA. 3) Dolomite \\
\hline 13 & Matrix inside chamber of foraminifer. & 0.77 & 0.94 & 0.23 & 0.23 & 26.33 & 0.72 & 0.02 & 51.09 & 0.01 & 0.28 & 80.62 & 1) CFA \\
\hline 13 & Foraminifer test. & 0.05 & 1.87 & 0.26 & 0.05 & 0.10 & 0.04 & 0.01 & 53,57 & 0.03 & 1.79 & 57.77 & 1) $\mathrm{Mg} / \mathrm{Fe}$ calcite \\
\hline 13 & Foraminifer test. & 0.07 & 4.35 & 0.11 & 0.02 & 1.42 & 0.25 & 0.05 & 54.17 & 0.06 & 0.53 & 61.03 & 1) $\mathrm{Mg}$ calcite \\
\hline 14 & Brown micritic matrix below CFA cement. & 0.43 & 0.75 & 0.07 & 0.01 & 18.91 & 0.61 & 0.00 & 53.51 & 0.03 & 0.10 & 74.43 & 1) CFA, 2) $\mathrm{Mg}$ calcite \\
\hline 15 & Phosphatized carbonate matrix. & 0.04 & 1.39 & 0.01 & 0.01 & 1.70 & 0.11 & 0.01 & 56.14 & 0.04 & 0.00 & 59.45 & 1) Dolomite. 2) CFA \\
\hline 15 & Phosphatized carbonate matrix. & 0.00 & 0.74 & 0.10 & 0.09 & 5.72 & 0.14 & 0.00 & 57.23 & 0.01 & 0.18 & 64.22 & 1) Dolomite, 2) CFA \\
\hline 16 & Seam of CFA cement veneer. & 0.66 & 0.75 & 0.06 & 0.01 & 25.74 & 1.23 & 0.01 & 51.92 & $0.0 \mathrm{I}$ & 0.16 & 80.55 & 1) $\mathrm{CFA}$ \\
\hline 17 & Dark brown matrix beneath CFA cement. & 0.05 & 3.72 & 0.40 & 0.07 & 0.40 & 0.18 & 0.02 & 50.69 & 0.02 & 1.94 & 57.50 & 1) Dolomite \\
\hline 18 & Fine micritic matrix. & 0.10 & 1.40 & 0.02 & 0.01 & 0.12 & 0.17 & 0.01 & 55.38 & 0.05 & 0.04 & 57.30 & 1) Dolomite \\
\hline 19 & Matrix inside chamber of foraminifer. & 0.09 & 6.85 & 0.09 & 0.06 & 0.19 & 0.05 & 0.02 & 50.46 & 0.08 & 0.25 & 58.12 & 1) Dolomite \\
\hline 20 & Foraminifer test. & 0.02 & 9.05 & 0.00 & 0.01 & 0.05 & 0.18 & 0.01 & 56.67 & 0.01 & 0.02 & 66.01 & 1) Dolomite \\
\hline 21 & Amber-stained foraminifer test. & 0.02 & 5.66 & 0.10 & 0.22 & 0.16 & 0.04 & 0.00 & 49.25 & 0.01 & 0.34 & 55.79 & 1) Dolomite \\
\hline
\end{tabular}

"Total iron.

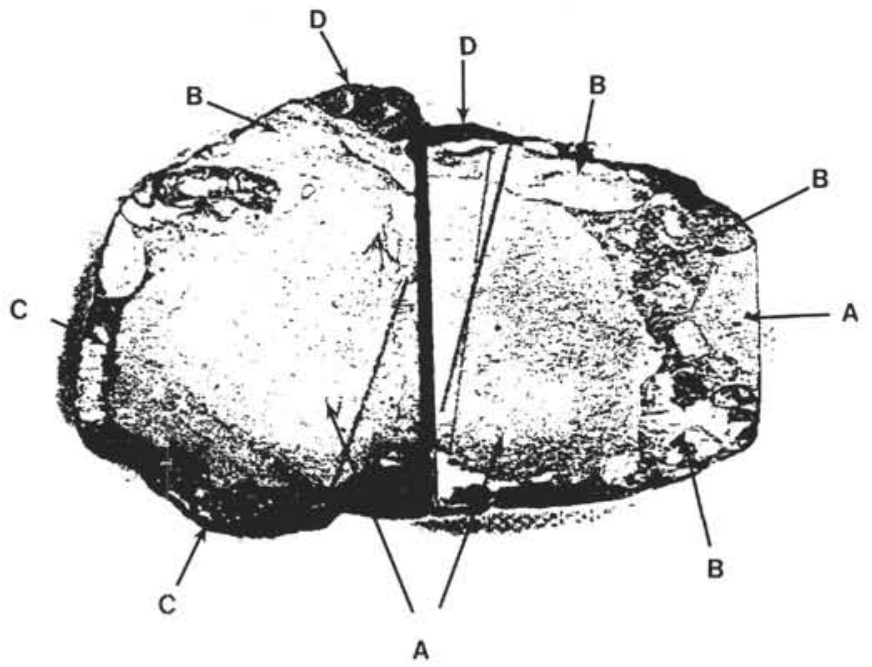

Figure 2. Photograph of uppermost nodule and crusts recovered at Hole 812C. A. Nodule composed of packed biomicritic wackestone to packstone. B. Layers of CFA cement veneered biomicritic wackestones and packstones; layers have been variably phosphatized and display moldic and vuggy porosity infilled with concentric growths of void-filling dolomite and sparry calcite. C. Botryoidal and finely laminated CFA/goethite crust. D. Finely laminated CFA/goethite crust. Laminations are at high angles to the underlying layers of sediment (Sample $133-812 \mathrm{C}-4 \mathrm{X}-1,0-3 \mathrm{~cm}$; horizontal dimension [HD] of sample $=5.75 \mathrm{~cm}$ ). Three stages of hardground development are inferred here. The first is the formation of dolomite and CFA cemented nodule (A). This was followed by the successive binding of individual sediment layers by phosphatic seams and replacement cements (B), and final precipitation of CFA/goethite crusts (C, D).

2, 3,4) and, perhaps, infaunal bioturbation (cf. Garrison et al., 1987) likely contributed to periodic rupturing and fracturing of the hardground surface. Throughout its genesis, the hardground was subjected to extensive diagenetic alteration, as evidenced by dissolution of aragonitic tests, formation of secondary vuggy porosity, and precipitation of void-filling submarine dolomite and calcite cements, as discussed below. Although we can see only what has been recovered at Sites 812 and 814 , we speculate that a widespread area of the QLP may be blanketed by this hardground deposit.

At Site 812, the uppermost portion of the hardground is composed of well-lithified, phosphatized planktonic- and benthic-foraminiferrich and calcareous-nannofossil-rich biomicrite nodules and numerous subsequent layers of differentially phosphatized, biomicritic wackestone and packstone (Figs. 5, 6, and 7). Each successive layer of accumulated sediment has been interpreted to represent one period of deposition. Between the layers, a veneer or seam of pure phosphatic cement (Figs. 6,7) appears to have precipitated during a period of nondeposition and, therefore, marks a boundary that likely represents a depositional hiatus. These seams are virtually identical to phosphate coatings that crosscut phosphorite nodules and crusts and that line cavities and pores (fringe cements) reported from modern Peru margin (Glenn and Arthur, 1988; Garrison and Kastner, 1990) and Southwest African shelf (Baturin, 1982) upwelling sediments. These seams also are virtually identical to cements variously described from hardgrounds capping limestones elsewhere (Anglada et al., 1975; Carter et al., 1982; Krajewski, 1984; Garrison et al., 1987). The layers of sediment tend to be uneven and discontinuous and, thus, appear to have been subjected to periodic stages of submarine erosion and winnowing. The upper surface of each sedimentary layer is interpreted to represent a micro-unconformity.

Current activity during periods of very slow or no net deposition should have been sufficient to differentially winnow and erode sediments on the seafloor. During formation of these hardgrounds, there were periods of nondeposition and stability. During these periods, a phosphatic cement veneered the existing surface. A new episode of sedimentation would cover this veneered surface, only to be differentially eroded sometime thereafter. This is recorded on spatial scales of centimeters within the hardground layers (Fig. 7A). In some areas, the sediment would be eroded back to the veneered surface; in other areas, particularly within micro-topographic lows, a small accumulation of sediment would be preserved. Subsequently, during the next period of nondeposition, new phosphatic cementation would create a new veneer on the surface that had been partly covered with the new sediment and partly with a veneer surface from the previous episode of cementation. This complex veneering produces a bifurcating cement seam that is only 5 to $20 \mu \mathrm{m}$ thick (Fig. 7A). 


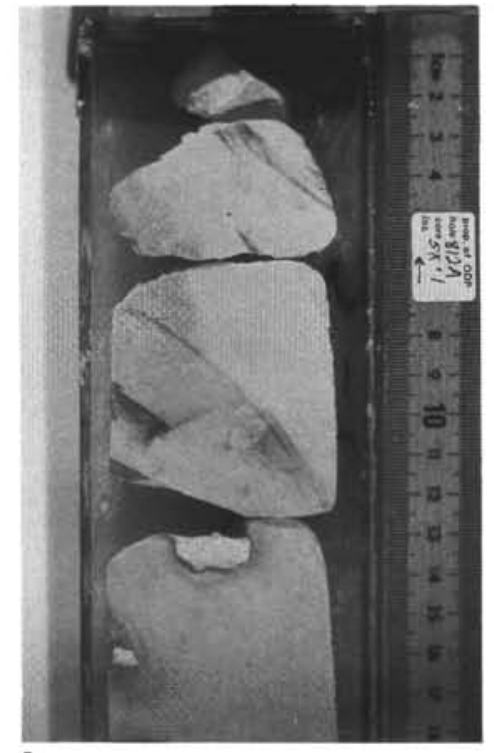

A

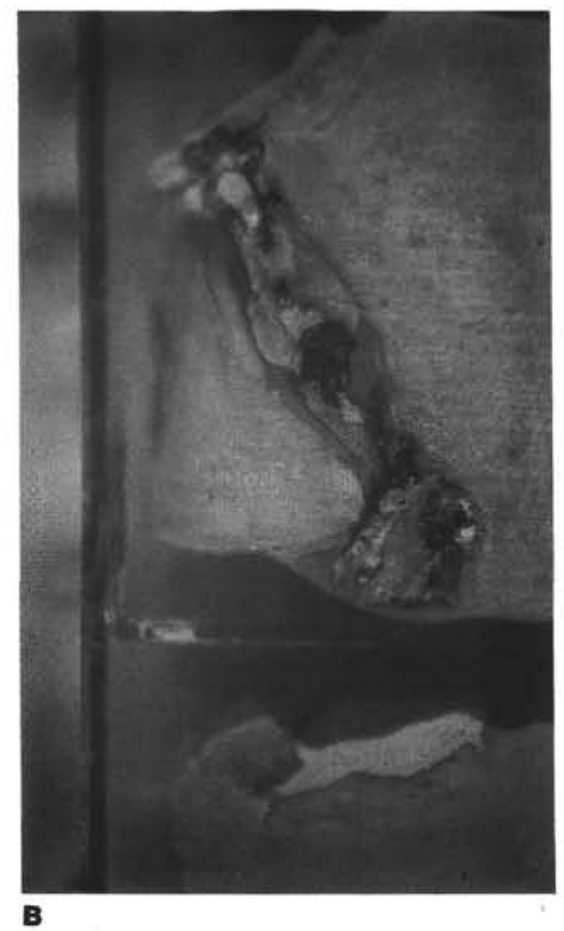

Figure 3. Photographs of hardground deposits from Hole 812A. A. Sawcut side of well-lithified bioclastic foraminiferal wackestone to packstone. Note the boring at 13-14 cm, which has been infilled with phosphatic carbonate mudstone (Sample 133-812A-5X-1, 0-18 cm; vertical dimension [VD] of photo $=20 \mathrm{~cm}$ ). B. External side of sample in $(A)$, between 6 and $14 \mathrm{~cm}$. Note large boring filled in with multiple generations of phosphatic cements (Sample 133-812A-5X-1, 6-14 cm; VD = $8 \mathrm{~cm}$ ).

\section{Aragonite Dissolution on the Seafloor}

Aragonite dissolution on the seafloor is evidenced in the QLP hardgrounds by the dissolution of aragonite gastropod tests that have been subsequently filled in with soft, foraminifer-bearing sediment (Fig. 8). Seafloor dissolution of the aragonite forming the gastropod tests is suggested because the sediment filling in the moldic porosity was soft at the time of deposition, and because no evidence indicates that these layers ever resided at depths shallower than $200 \mathrm{~m}$ below

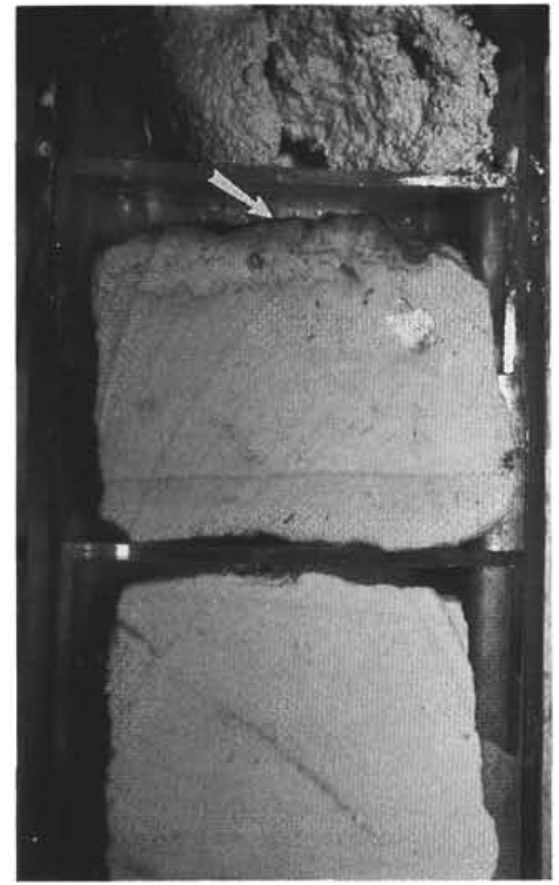

A

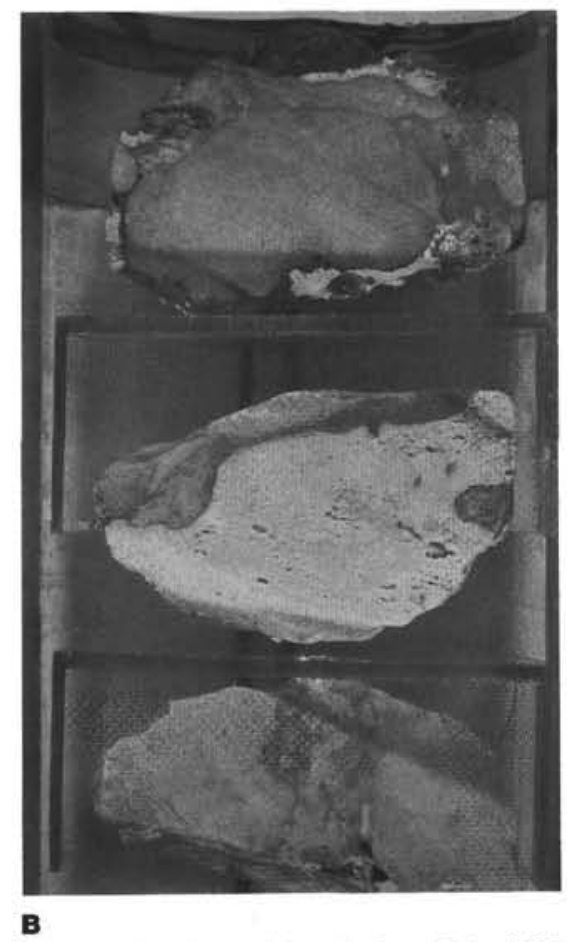

Figure 4. Photographs of hardground deposits from Holes 812B and 812C.A. Arrow points to uppermost surface of hardground. Overlying the hardground is a ca. 3.0 Ma unlithified foraminifer ooze marking an abrupt change in lithology. The hardground itself (ca. 3.0-3.45 Ma) has been capped by a veneer of intermixed CFA and goethite (Sample 133-812B-1W-1, 2-15 cm; VD = 13 $\mathrm{cm})$. B. Well-developed hardground nodules displaying complex lithologies representative of long periods of little or no deposition, combined with the effects of submarine erosion and winnowing. Note well-developed boring with phosphatic material filling in lowermost core piece (Sample 133-812C-4X-1, $0-12 \mathrm{~cm} ; \mathrm{VD}=13 \mathrm{~cm}$ ). 


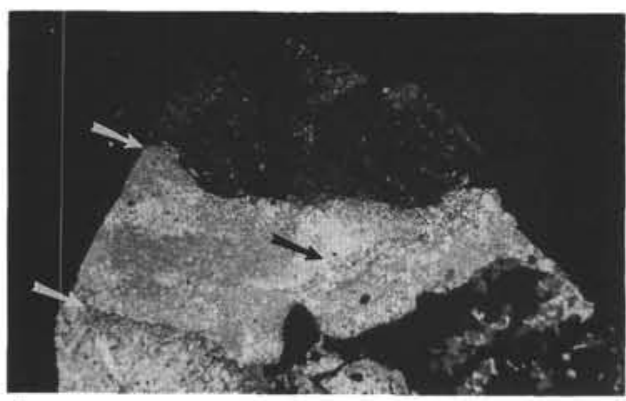

A

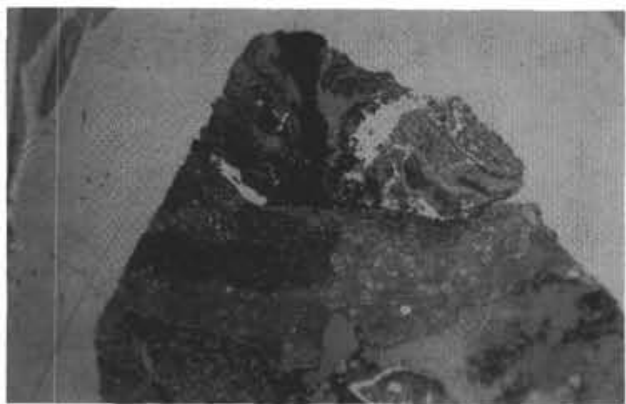

B

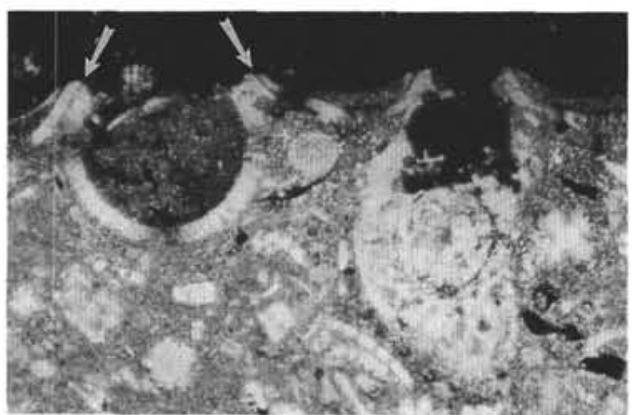

C

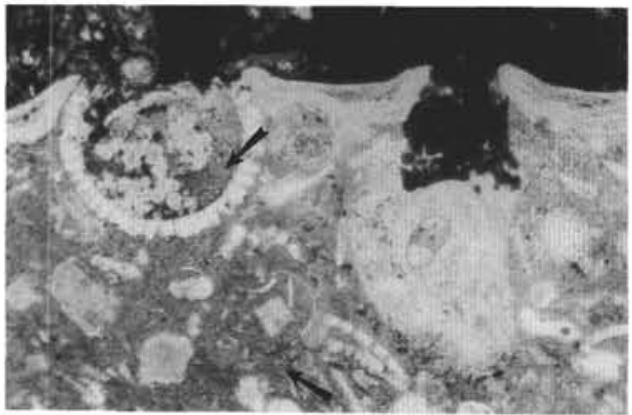

D

Figure 5. Photomicrographs of thin sections showing the complex lithologic relationships found in the nodular phosphatic carbonate hardgrounds. A. Successive layers of bioclast and foraminifer-rich micritic wackestones and packstones are bounded by seams of CFA cement (arrows). Note the uppermost layer is isotropic because of precipitation of a red-brown crust of complexly layered CFA and goethite (Sample 133-812C-4X-1, 0-3 cm; cross polarized; horizontal dimension $[\mathrm{HD}]$ of photo $=15 \mathrm{~mm}$ ). B. Same view as in (A), but in plane light; note banded appearance of complexly layered CFA and goethite. C. Micro-unconformity boundary between wackestone below and layered CFA and goethite above. The CFA cement veneer above the wackestone appears as a thin double-layered seam (arrows). Note that the two foraminifer tests and the overlying seam have been eroded away before precipitation of the discordant layered CFA and goethite. The eroded open foraminifer chamber-filling sediments have been either phosphatized (left), or replaced by CFA/ goethite (right) (Sample 133-812C-4X-1, 0-3 cm; cross polarized; $\mathrm{HD}=0.97$ $\mathrm{mm})$. D. Same view as in C, but in plane light; note the dark color of the micritic matrix that has undergone phosphatization (arrow).
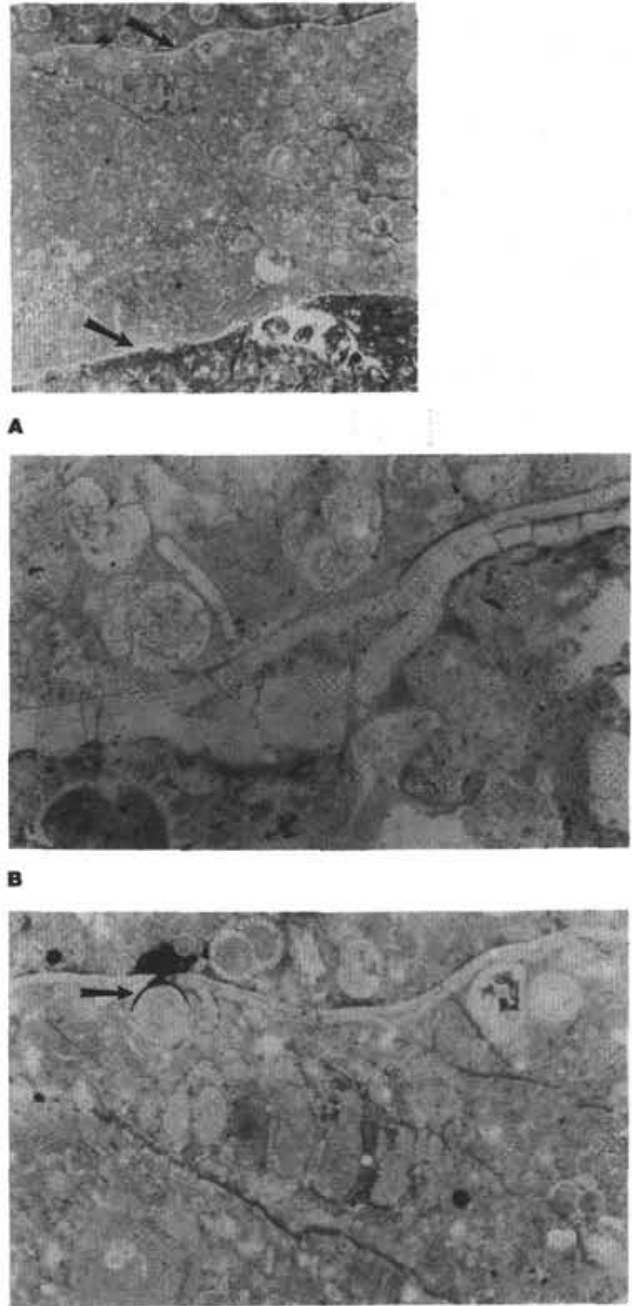

C

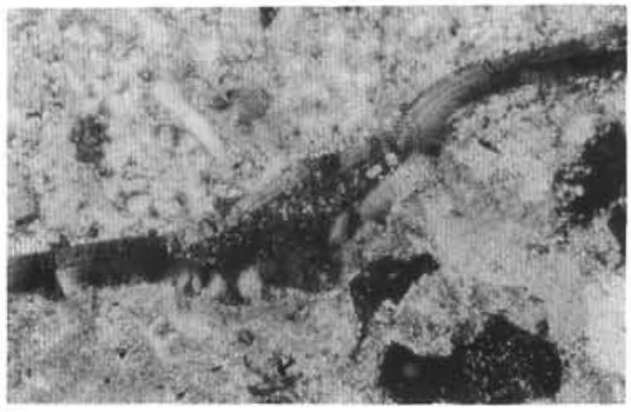

D

Figure 6. Photomicrographs of thin sections showing layers of packstone and wackestone separating double-layered veneer seams of pure CFA cement (arrows). A. Note varied colors of matrix from one layer to another (Sample 133-812C-4X-1, 0-3 cm; plane light; $\mathrm{HD}=6 \mathrm{~mm}$ ). B. Bifurcation of CFA seam containing infills of phosphatized wackestone (Sample 133-812C-4X-1, 0-3 $\mathrm{cm}$; plane light; $\mathrm{HD}=0.485 \mathrm{~mm})$. C. Note leakage of $\mathrm{CFA} /$ goethite cement across CFA seam (arrow) (Sample 133-812C-4X-1, 0-3 cm; plane light; HD $=1.94 \mathrm{~mm}$ ). D. Same view as in (B) with cross polarization. Note that the CFA in the seam is pseudoisotropic and appears almost chalcedonic in texture; the CFA crystallines are aligned nearly at right angles to the plane of the seam; CFA mineralogy confirmed by XRD, EMP, and EDS (Sample 133-812C-4X-1, $0-3 \mathrm{~cm}$; cross polarized; $\mathrm{HD}=0.485 \mathrm{~mm}$ ). 


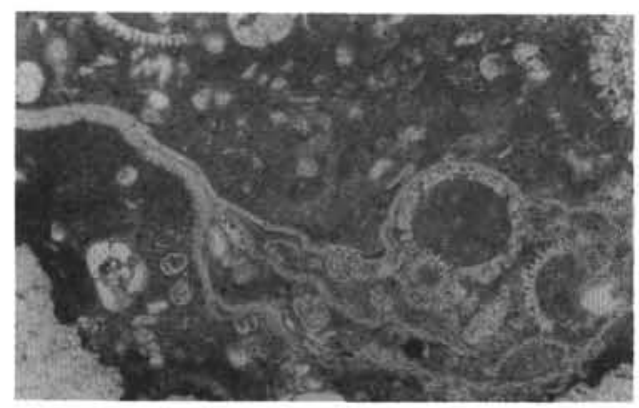

A

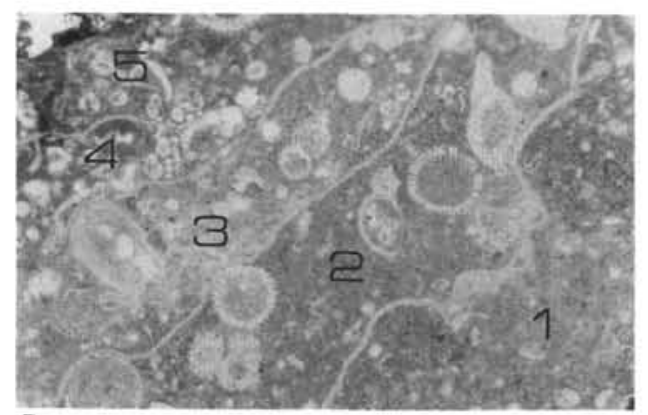

B

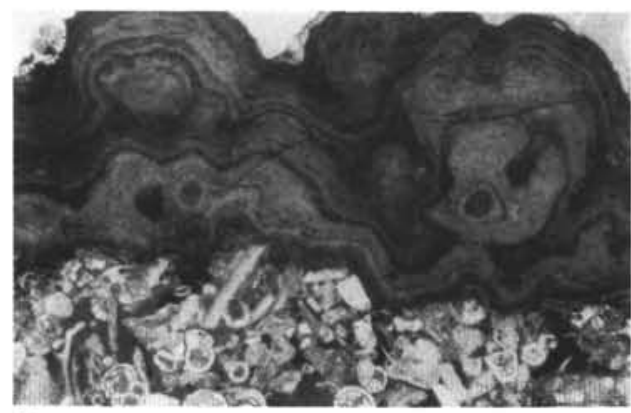

c

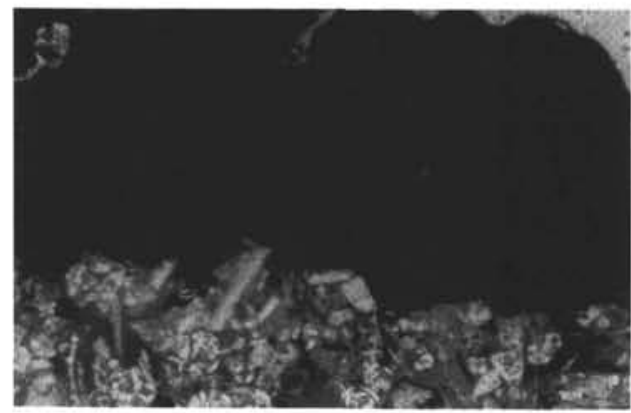

D

Figure 7. A. Bifurcating pure CFA seam cements enclose discrete layers of packstones and wackestones (Sample 133-812C-4X-1, 0-3 cm; plane light; $\mathrm{HD}=0.97 \mathrm{~mm}$ ). B. Five layers of packstone and wackestone separated by layered veneer seams of pure CFA cement (Sample 133-812C-4X-1, 0-3 cm; plane light; $\mathrm{HD}=1.94 \mathrm{~mm}$ ). C. Finely laminated botryoidal CFA/goethite cement encrusting packstone nodule (Sample 133-812C-4X-1, 0-3 cm; plane light; $\mathrm{HD}=1.94 \mathrm{~mm})$. D. Same view as in $(C)$ but cross polarized; note anisotropism of crust.

sea level (Katz, this volume). Aragonite dissolution, therefore, must have taken place at or immediately adjacent to the seafloor. We suggest, therefore, that at this time the seafloor resided at or below the aragonite lysocline, and/or that there was convective (Kohout) flow of undersaturated pore waters through the sediments (Kohout et al., 1977; Mullins et al., 1985; Morse and Mackenzie, 1990).

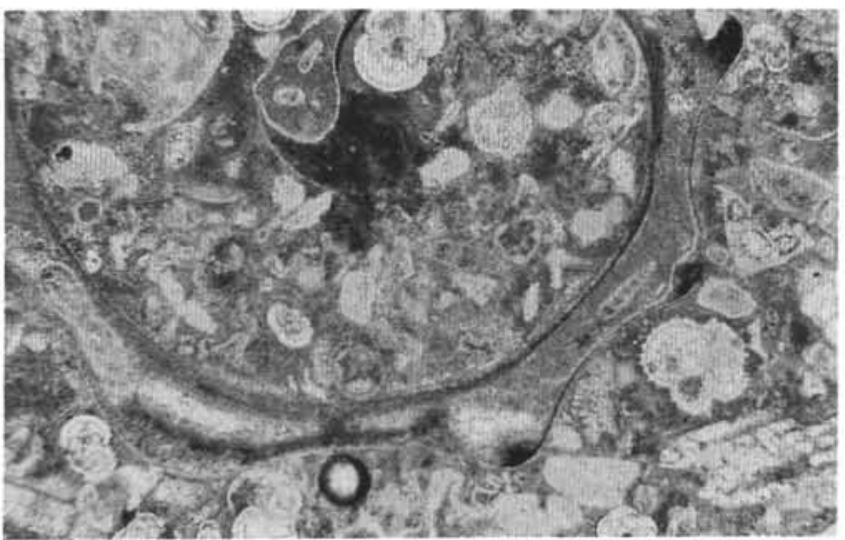

A

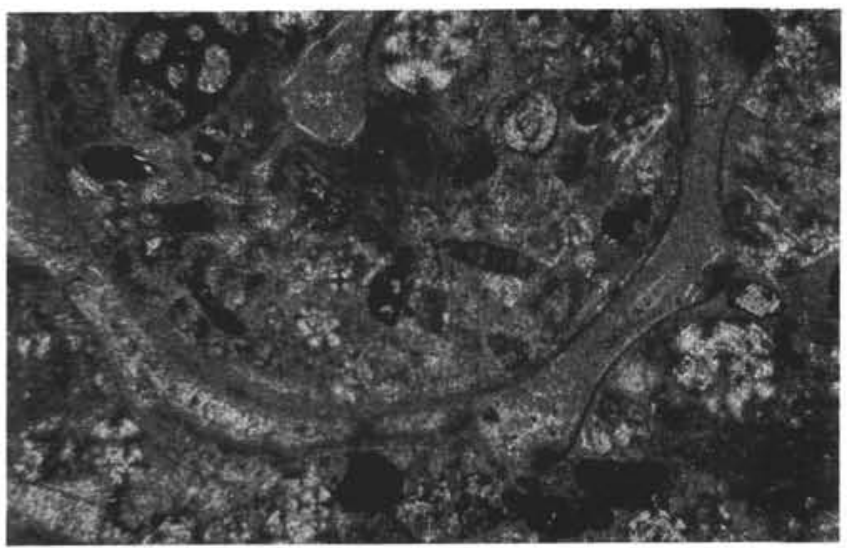

B

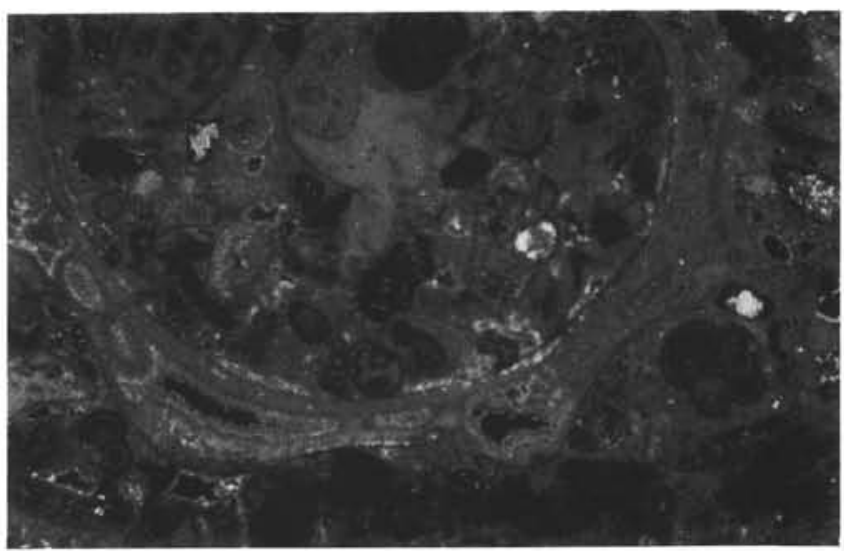

C

Figure 8. Concentric precipitation of dolomite followed by void infilling of sparry calcite (Sample 133-812C-4X-1, 0-3 cm). A. Plane light. B. Cross polarized. C. Cathodoluminescence $(\mathrm{HD}=1.1 \mathrm{~mm})$.

\section{Dolomite}

Dolomite in the QLP hardgrounds occurs as both a replacement after precursory carbonate matrix and as a moldic and interparticle void-filling cement. In thin section, dolomite is difficult to differentiate from other carbonates, but, inspected under cathodoluminescence, it typically shows well-defined zonations characteristic of the variations of its iron contents (Figs. 9 and 10). Its ferroan nature (about $0 \%-2.0 \% \mathrm{Fe}_{2} \mathrm{O}_{3}$ ) is confirmed by electron microprobe analyses (Table 1) and by energy dispersal spectrometry of thin sections under scanning electron microscope (SEM). Dolomite occurs after the 
formation of interparticle and moldic porosity and before the precipitation of sparry calcites, described below.

\section{Sparry Calcites}

Surprisingly, one of the last cements to precipitate within moldic and interparticle porosity in the hardgrounds is sparry calcite. These calcites are euhedral and, in some cases, display scalenohedral ("dogtooth") morphologies and are low in manganese and magnesium. In essence, in the absence of light stable isotope data, they are virtually identical to spar cements typically precipitated in freshwater phreatic or vadose pore-water environments. However, as discussed above, the paleobathymetric data for these sites preclude such an interpretation. Rather, as discussed below, we think that these sparry calcites are of open-marine origin.

\section{Botryoidal Iron Oxide Cements}

Encrusting iron oxide cements occur in the QLP hardgrounds as millimeter-scale, laminated layers and botryoidal coatings (Figs. 5 and 7). XRD, EMP, and EDS studies of these layers show that they are actually a complicated intergrowth of goethite, carbonate fluorapatite, and likely gibbsite (as indicated by traces of aluminum). They are red-brown in transmitted light and exhibit spotty distribution of anisotropism under crossed nicols, with the latter the result of carbonate fluorapatite interlayering. Because of the dominance of oxidized iron $\left(\mathrm{Fe}^{3+}\right)$ and the general absence of manganese $\left(\mathrm{Mn}^{2+}\right)$, these cements display very poor to no cathodoluminescence.

\section{DISCUSSION}

\section{Precipitation of Calcite Spar and the Dissolution of Aragonite}

The above discussions have shown that the precipitation of sparry cements and aragonite dissolution are two marked features associated with QLP hardground development. In shallow-water Holocene carbonate sediments, both of these features are commonly interpreted as the result of freshwater diagenesis (e.g., Folk, 1974; Bathurst, 1975; Longman, 1980). However, in the case of the QLP sediments, it is difficult to invoke incursions of fresh water to explain these features because, despite variations in sea level, benthic foraminiferal assemblages for these sediments indicate subsidence and deepening of Sites 812,813 , and 814 and other nearby sites from outer neritic depths $(100-300 \mathrm{~m})$ in the middle Pliocene to upper bathyal depths (200-600 $\mathrm{m}$ ) through the late Pliocene and Pleistocene (Katz and Miller, 1991; Katz, this volume). In addition, despite their general lack of notoriety, marine sparry calcites have been variously documented. These include rhombic, polyhedral, low-magnesium calcite spars recovered from the Tongue of the Ocean in the Bahamas (Schlager and James, 1978); in-situ spars from Pleistocene periplatform sediments in the northern Bahamas (Mullins et al., 1985); spars in Miocene-age chalks and limestones at ODP Site 632 in the Bahamas (Dix and Mullins, 1988); Campanian-age spars cementing gravity flow deposits in the Bahamas (McClain et al., 1988); void-filling spars in gastropod molds in Bahamian perireef sediments (Freeman-Lynde, 1988); spars from shallow seas near England (Al-Hashimi, 1977) and Tasmania (Rao, 1981); and spars from Mesozoic marine hardgrounds that crop out in Europe (Garrison et al., 1987) and North America (Wilkinson et al., 1985). Thus, rather than call upon freshwater diagenesis to explain the sparry calcites present in the Pliocene-Pleistocene hardgrounds of the QLP, we suggest that the presence of sediment and calcite-spar filled-in aragonite molds is the result of an interplay between shoalings of the aragonite lysocline and the aragonite saturation level in intermediate water masses and the subsequent precipitation of sparry calcite marine cements. For example, Droxler et al. (1990) convincingly demonstrated from examination of upper Pliocene-Pleistocene $(2.0-0.3 \mathrm{Ma})$ aragonite supercycles in shallow-water Maldives Hole

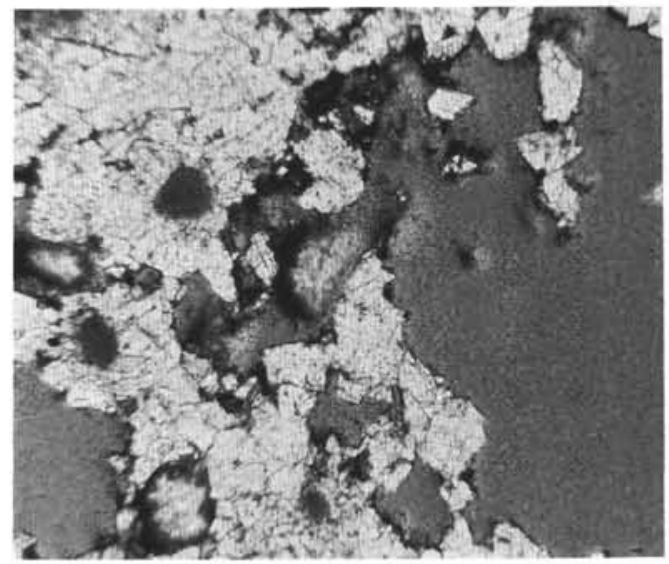

A
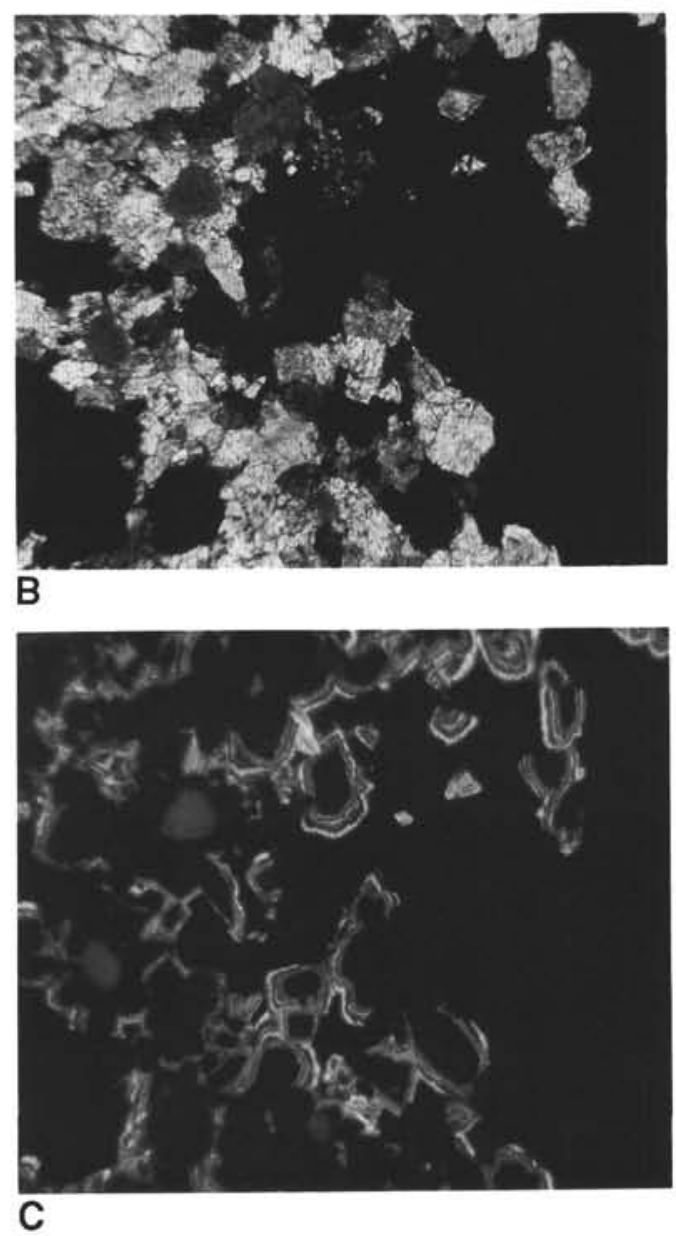

Figure 9. Compositionally zoned ferroan-dolomite in vug (Sample 133-812C$4 \mathrm{X}-1,0-3 \mathrm{~cm})$. A. Plane light. B. Cross polarized. C. Cathodoluminescence $(\mathrm{HD}=1.1 \mathrm{~mm})$.

$716 \mathrm{~B}$ that aragonite saturation levels reached water depths shallow enough to be located within the oxygen minimum zone. In the central Pacific today $\left(18^{\circ} \mathrm{N}\right)$, the shallow aragonite saturation level resides at 300 to $400 \mathrm{~m}$ (Berner, 1977), and studies from the Nicaragua Rise (Caribbean) also show oxygen minimum waters at 700 to $1000 \mathrm{~m}$ that occur at or just below the shallow aragonite saturation horizon (Droxler et al., 1990). In the Caribbean, deeper waters become saturated again at 1000 and $1900 \mathrm{~m}$ and, finally, become fully undersaturated at or below $1900 \mathrm{~m}$ (Droxler et al., 1988). Upon aragonite dissolution, excess alkalinity may be generated to promote the precipitation of 


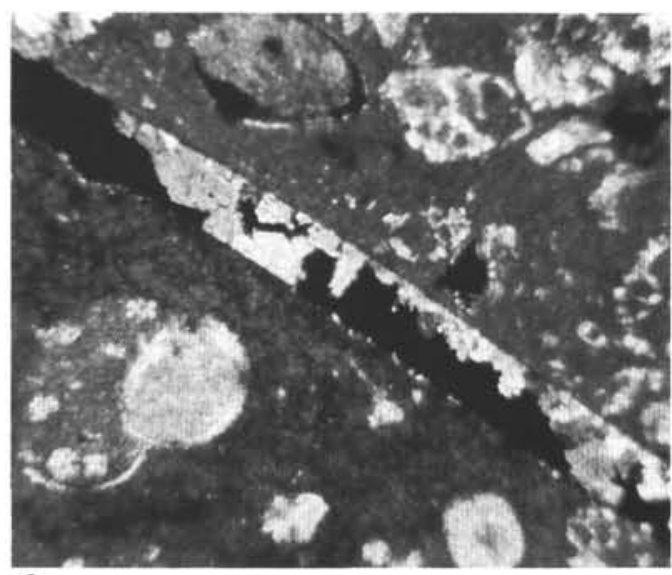

A

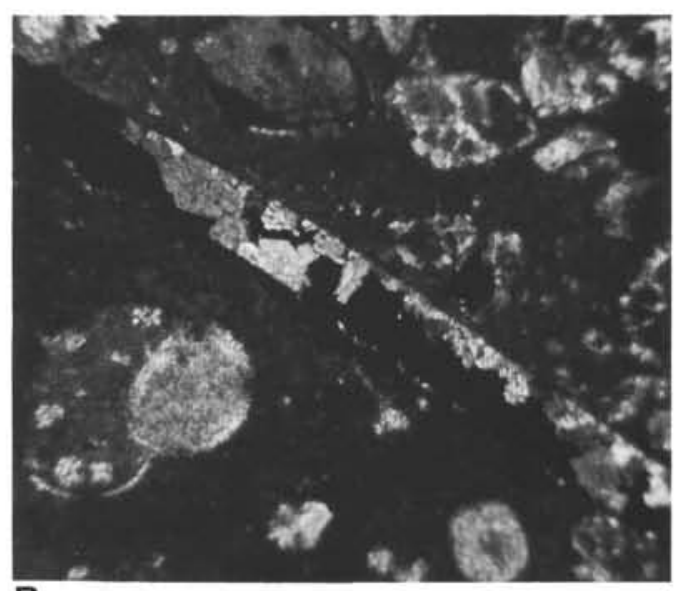

B

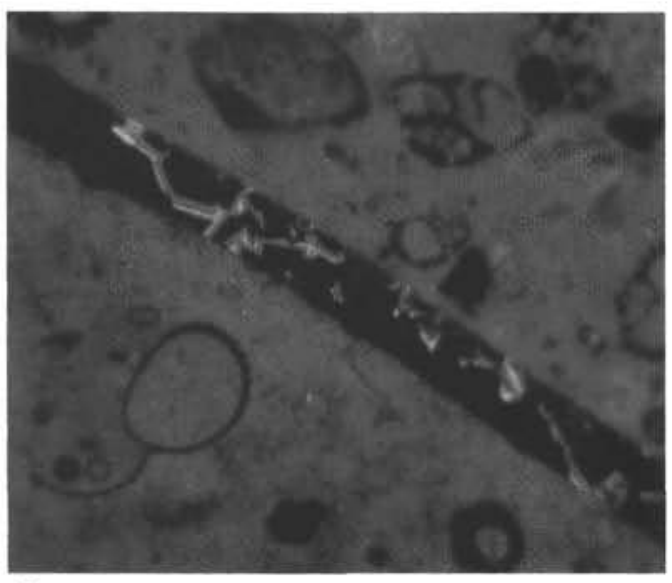

C

Figure 10. Compositionally zoned ferroan-dolomite in moldic pore (Sample 133-812C-4X-1, 0-3 cm). A. Plane light. B. Cross polarized. C. Cathodoluminescence $(\mathrm{HD}=1.1 \mathrm{~mm})$.

sparry calcites. As discussed below, a coincidence of the shallow aragonite saturation horizon with the oxygen minimum zone may also explain the high concentrations of iron, manganese, and carbonate fluorapatite in the QLP hardground cements.

\section{Precipitation of Phosphatic Cements and Redox Gradients}

How can we reconcile the co-occurrence of phosphatic and goethitic hardground development, aragonite dissolution on the seafloor, and Mn-bearing carbonate cements and replacement products? The carbonate fluorapatites of the QLP hardgrounds show a complete absence of cathodoluminescence, as well as very low levels of $\mathrm{MnO}$, as detected by electron microprobe, and this is consistent with other studies of marine carbonate fluorapatites (e.g., Glenn and Arthur, 1988; Glenn, 1990b). We think that this is not because of the availability of dissolved $\mathrm{Mn}$ in pore waters, but, rather, because CFA does not normally accommodate $\mathrm{Mn}^{2+}$ in its structure. However, based on our electron microprobe and cathodoluminescence data, the abundance of manganese in the QLP hardgrounds strongly suggests that the pore waters influencing cement precipitation were, in fact, reducing. Further, the zoning in the dolomites of the hardgrounds is produced by included reduced iron that also acts as a cathodoluminescence activator. Because organic carbon contents are extremely low (about $0.1 \%-0.0 \%$ ) and because pyrite is nil in these sediments, the redox conditions in the sediments apparently were not anoxic and strongly reducing (such as for normal coastal upwelling zone sediments), but, rather, mildly reducing. In addition to in-situ decomposition of organic matter in the sediments, it is also possible that an impingement of a mid-water oxygen minimum zone on the QLP during late Pliocene times facilitated reducing conditions. This also would have resulted in bathing the QLP with phosphorus-enriched bottom waters. As noted above, intermediate-water aragonite dissolution occurs in many places in the world where the aragonite lysocline intersects the relatively acidic waters associated with oxidative bacterial degradation of organic matter in the water column. The abundance of pelagic microfauna contained in the QLP hardgrounds seems to indicate that the surface waters overlying these sediments were at least moderately fertile.

In light of our observations, we envision that the likely supply of phosphorus to these hardgrounds was seawater and suggest that the complex interlayering of CFA and goethite in them is a result of iron redox-controlled pore-water pumping of iron. In oxygenated waters, FeOOH compounds sorbed phosphate, but upon encountering reducing conditions, this sorbed phosphate is released (Froelich et al., 1979; Krom and Berner, 1980, 1981; de Lange, 1986; Schaffer, 1986) and is available for precipitation as a primary authigenic phase (e.g., O’Brien et al., 1988; Froelich et al., 1988; Schuffert, 1988; Glenn and Arthur, 1990; Glenn, 1990a, 1990b). The iron reduced in this process, perhaps by microbial mediation, becomes available for incorporation in other authigenic phases (the dolomites of the QLP hardgrounds) or may be fluxed by chemical gradient back to the relatively more oxygenated seafloor, where the $\mathrm{Fe}^{2+}$ is re-oxidized and re-precipitated (the goethite of the QLP hardgrounds). There, the freshly precipitated FeOOH can sorb more dissolved $\mathrm{PO}_{4}{ }^{3-}$ before being buried back into the sediments. The seafloor adsorption of phosphorus by iron compounds should be especially favored by low sedimentation rates, because, during such intervals, the compounds remain in contact with bottom waters for extended periods of time before burial.

We are unsure about the origin of the ferroan dolomite in the QLP hardgrounds. Its formation appears to have occurred relatively late with respect to the remainder of the hardground mass because it occurs as both a void-filling cement and a groundmass-replacement product. Its formation may be tied to seawater pumping in the QLP via thermally driven Kohout circulation processes (it may even be forming today), and/or it may have been related to the increases in carbonate alkalinity associated with aragonite dissolution. In the absence of other supporting data, it seems likely that the magnesium needed to form these dolomites is from continuous convective pumping of normal seawater.

\section{Paleoceanographic Implications}

The complex assemblage of diagenetic and authigenic minerals of the Pliocene hardgrounds on the Queensland Plateau represents approximately $1 \mathrm{~m}$ of net deposition in a current-swept regime that persisted for approximately 450,000 years between 3.45 and 3.0 Ma. 
Nannofossil datums 2.29 and $3.45 \mathrm{Ma}$ (Gartner et al., this volume) bracket the hardground interval (Fig. 1), and the amount of sediment present between these datums decreases (becomes more condensed) with decreasing water depth, from $\sim 27 \mathrm{~m}$ at Site 813 (539 m below present sea level, where only minor transported fragments from the hardgrounds occur) to $\sim 5 \mathrm{~m}$ at Site 812 ( $455 \mathrm{~m}$ below present sea level). This increasing condensation toward shallower depths (Fig. 1) implies that late Pliocene current intensity and/or duration was greater at the shallower intermediate water depths. We speculate that currents washing the QLP in late Pliocene times were ancient intermediate water equivalents of either the Subtropical Lower or Antarctic Intermediate water masses, both of which presently inundate the QLP provenience from the east. In addition, the timing of the hiatus and hardground development appears to correlate with dramatic increases in global oceanic current activity (e.g., Moore et al., 1977, 1978; Mayer, et al., $1985,1986)$ accompanying the late Pliocene ice age transition (e.g., Kennett, 1982; Shackleton and Hall, 1984; Hodell et al., 1985; Raymo et al., 1989; Joyce et al., 1990). The rise of the lysocline at about this time, as inferred from our petrographic observations, appears to correlate with marked pulses in deep sea carbonate dissolution (elevations of the calcite lysocline and critical depths) at about 3.45 and 3.2-3.0 $\mathrm{Ma}$ in the equatorial Pacific Ocean (Farrell and Prell, 1991). The termination of hardground development on the QLP at ca. $3 \mathrm{Ma}$ is marked by a return to pelagic sedimentation of nannofossil foraminiferal oozes (Fig. 1), a major sea-level fall (Haq et al., 1988), a positive shift in planktonic d180 in nearby Hole $818 \mathrm{~B}$ (Droxler et al., this volume), a significant increase in ice volume (Prell, 1985; Keigwin, 1986; Shackleton and Hall, 1984; Curry and Miller, 1989), and a dramatic lowering of the lysocline and calcite compensation depths in the equatorial Pacific Ocean (Farrell and Prell, 1991).

\section{CONCLUSIONS}

The late Pleistocene age hardgrounds occurring on the Queensland Plateau are marked by a complex assemblage of diagenetic and authigenic minerals representing approximately $1 \mathrm{~m}$ of net deposition in a current-swept regime that persisted for approximately 450,000 years. The timing of the hardgrounds' development appears to correlate with a marked increase in paleowater depths, from outer neritic to upper bathyal. The mineral assemblage contained in these hardgrounds includes carbonate fluorapatite, ferroan to nonferroan dolomite, marine sparry calcites, and goethite having minor amounts of gibbsite. Current reworking transported some grains from the shallower water sites of hardground development (e.g., Sites 812 and 814) to deeper water sites of deposition (e.g., Site 813). The dissolution of aragonite and the phosphatization of carbonates in the hardgrounds are thought to be connected to a coincidence of a mid-water aragonite lysocline and oxygen minimum zone, although aragonite dissolution also may have been facilitated by Kohout pumping of marine waters through the Queensland Plateau. The intimate co-occurrence of iron oxides and goethite layers suggests that a pore-water iron-pumping mechanism may have been involved in which oxidized iron compounds transport sorbed phosphorus to pore waters, whereupon phosphorus and reduced iron are subsequently released upon reduction. The phosphorus released is available for precipitation as carbonate fluorapatite. The reduced iron becomes scavenged during the precipitation of dolomite and goethite and/or refluxes back to the sediment/water interface, where it may be re-oxidized and again sorb phosphorus. Based on paleobathymetric data, the dissolution of aragonite and the presence of sparry calcites in the hardgrounds are not thought to be the result of the incursion of fresh waters, but, rather, appear to have originated in an open-marine setting.

\section{ACKNOWLEDGMENTS}

We are pleased to acknowledge financial support for this project provided by a grant from the U.S. Scientific Advisory Committee
(USSAC). We also gratefully thank Robert E. Garrison and Peter N. Southgate for their reviews of the manuscript. To our co-chiefs and colleagues and the ship and drilling crews of JOIDES Resolution, we express our gratitude for their helpfulness and cooperation. This is a contribution to IGCP Project 325 "Palaeogeography of Authigenic Minerals and Phosphorites," and is University of Hawaii SOEST Contribution No. 3186.

\section{REFERENCES}

Al-Hashimi, W.S., 1977. Recent carbonate cementation from seawater in some weathered dolostones, Northumberland, England. J. Sediment. Petrol., 47:1375-1391.

Anglada, R., Froget, C., and Recy, J., 1975. Sedimentation ralentie et diagenese sous-marine au se de la nouvelle-caledonie (dolomitisation, ferruginisation, phosphatisation). Sediment. Geol., 14:301-317.

Bathurst, R.G.C., 1975. Carbonate Sediments and Their Diagenesis (2nd ed.): New York (Elsevier).

Baturin, G.N., 1982. Phosphorites on the Sea Floor: Origin, Composition and Distribution: Amsterdam (Elsevier), Dev, in Sedimentol. Ser., 33.

Berner, R.A., 1977. Sedimentation and dissolution of pteropods in the ocean. In Andersen, N.R., and Malahoff, A. (Eds.), The Fate of Fossil Fuel $\mathrm{CO}_{2}$ in the Oceans: New York (Plenum), 243-260.

Burnett, W.C., Cullen, D.J., and McMurtry, G.M., 1987. Open-ocean phosphorites-in a class by themselves? In Teleki, P.G., et al. (Eds.), Marine Minerals: Dordrecht (D. Reidel), 119-134.

Carter, R.M., Linquist, J.K., and Norris, R.J., 1982. Oligocene unconformities and nodular phosphate hard ground horizons in western Southland and northern West coast. J, R. Soc. N.Z., 12:11-46.

Curry, W.B., and Miller, K.G., 1989. Oxygen and carbon isotopic variation in Pliocene benthic foraminifers of the equatorial Atlantic. In Ruddiman. W., Sarnthein, M., et al., Proc. ODP, Sci. Results, 108: College Station, TX (Ocean Drilling Program), 157-166.

De Carlo, E.H., and Fraley, C., 1992. Chemistry and mineralogy of ferromanganese deposits from the south Equatorial Pacific Ocean. In Keating B., and Bolton, B. (Eds.), Geology and Offshore Mineral Resources of the Central Pacific Basin. Circum-Pac. Counc. Energy Miner. Resour., Earth Sci. Ser., 14:225-245.

de Lange, G.J., 1986. Early diagenetic reactions in interbedded pelagic and turbidic sediments in the Nares Abyssal Plain (western North Atlantic): consequences for the composition of sediment and interstitial water. Geochim. Cosmochim. Acta, 50:2543-2561.

Dix, G.R., and Mullins, H.T., 1988. Rapid burial diagenesis of deep water carbonates: Exuma Sound Bahamas. Geology, 16:680-683.

Droxler, A.W., Glaser, K.S., Morse, J.W., and Baker, P.A., 1988. Good agreement between carbonate mineralogical depth variations of surficial periplatform ooze and carbonate saturation levels of overlying intermediate water. New data from the Nicaragua Rise. Eos, 69:1233.

Droxler, A.W., Haddad, G.A., Mucciarone, D.A., and Cullen, J.L., 1990. Pliocene-Pleistocene aragonite cyclic variations in Holes 714A and 716B (The Maldives) compared with Hole 633A (The Bahamas): records of climate-induced $\mathrm{CaCO}_{3}$ preservation at intermediate water depths. In Duncan, R.A., Backman, J., Peterson, L.C., et al., Proc. ODP, Sci. Results, 115: College Station, TX (Ocean Drilling Program), 539-577.

Farrell, J.W., and Prell, W.L., 1991. Pacific $\mathrm{CaCO}_{3}$ preservation and $\delta^{18} \mathrm{O}$ since $4 \mathrm{Ma}$ : paleoceanic and paleoclimatic implications. Paleoceanography, 6:485-498.

Folk, R.L., 1974. The natural history of crystalline calcium carbonate: effects of magnesium content and salinity. J. Sediment. Petrol., 44:40-53.

Freeman-Lynde, R.P., McClain, W.R., and Lohmann, K.C., 1988. Deep-marine origin of equant spar cements in Oligocene-Miocene Perireef Boundstones, Leg 101, Site 635, Northeast Providence Channel, Bahamas. In Austin, J.A., Jr., Schlager, W., et al., Proc. ODP, Sci. Results, 101: College Station, TX (Ocean Drilling Program), 255-261.

Froelich, P.N., Arthur, M.A., Burnett, W.C., Deakin, M., Hensley, V., Jahnke, R., Kaul, L., Kim, K.H., Roe, K., Soutar, A., and Vathakanon, C., 1988. Early diagenesis of organic matter in Peru continental margin sediments: phosphorite precipitation. Mar. Geol., 80:309-343.

\footnotetext{
Abbreviations for names of organizations and publication titles in ODP reference lists follow the style given in Chemical Abstracts Service Source Index (published by American Chemical Society).
} 
Froelich, P.N., Klinkhammer, G.P., Bender, M.L., Luedtke, N.A., Heath, G.R., Cullen, D., Dauphin, P., Hartman, B., Hammond, D., and Maynard, V. 1979. Early oxidation of organic matter in pelagic sediments of the eastern Equatorial Atlantic: suboxic diagenesis. Geochim. Cosmochim. Acta, 43:1075-1090.

Garrison, R.E., and Kastner, M., 1990. Phosphatic sediments and rocks recovered from the Peru margin during ODP Leg 112. In Suess, E., von Huene, R., et al., Proc. ODP, Sci, Results, 112: College Station, TX (Ocean Drilling Program), 111-134.

Garrison, R.E., Kennedy, W.J., and Palmer, T.J., 1987. Early lithification and hardgrounds in Upper Albian and Cenomanian Calcarenites, Southwest England. Cretaceous Res., 8:103-140.

Glenn, C.R., 1990a. Depositional sequences of the Duwi, Sibaiya and Phosphate Formations, Egypt: Phosphogenesis and glauconitization in a Late Cretaceous epeiric sea. In Notholt, A.J.G., and Jarvis, I. (Eds.), Phosphorite Research and Development. Geol. Soc. Spec. Publ. London, $52: 205-222$.

, 1990b. Pore water, petrologic and stable carbon isotopic data bearing on the origin of modern Peru margin phosphorites and associated authigenic phases. In Burnett, W.C., and Riggs, S.R. (Eds.), Phosphate Deposits of the World (Vol. 3): Genesis of Neogene to Recent Phosphorites: Cambridge (Cambridge Univ. Press), 46-61.

Glenn, C.R., and Arthur, M.A., 1988. Petrology and major element geochemistry of Peru margin phosphorites and associated diagenetic minerals: authigenesis in modern organic-rich sediments. Mar. Geol., 80:231-267.

, 1990. Anatomy and origin of a Cretaceous phosphorite-greensand giant, Egypt. Sedimentology, 37:123-154.

Halbach, P., Manheim, F.T., and Otten, P., 1982. Co-rich ferromanganese deposits in the central seamount regions of the Central Pacific Basin-results of the Midpac '81. Erzmetall, 35:447-453.

Hamilton, E.L., 1956. Sunken islands of the Mid-Pacific Mountains. Mem.Geol. Soc. Am., 64.

Haq, B.U., Hardenbol, J., and Vail, P.R., 1988. Mesozoic and Cenozoic chronostratigraphy and cycles of sea-level change. In Wilgus, C.K., Hastings, B.S., Kendall, C.G.St.C., Posamentier, H.W., Ross, C.A., and Van Wagoner, J.C. (Eds.), Sea-Level Changes-An Integrated Approach. Spec. Publ.-Soc. Econ. Paleontol. Mineral., 42:72-108.

Heggie, D.T., Skyring, G.W., O'Brien, G.W., Reimers, C., Herczeg, A., Moriarty, D.J.W., Burnett, W.C., and Milnes, A.R., 1990. Organic carbon cycling and modern phosphorite formation on the East Australian continental margin: an overview. In Notholt. A.J.G., and Jarvis. I. (Eds.), Phosphorite Research and Development. Geol. Soc. Spec. Publ. London, 52:87-117.

Hodell, D.A., Williams, D.F., and Kennett, J.P., 1985. Late Pliocene reorganization of deep vertical water-mass structure in the western South Atlantic: faunal and isotopic evidence. Geol. Soc. Am. Bull., 96:495-503.

Jahnke, R.A., Emerson, S.R., Roe, K.K., and Burnett, W.C., 1983. The present day formation of apatite in Mexican continental margin sediments. Geochim. Cosmochim. Acta, 47:259-266.

Joyce, J.E., Tjalsma, L.R.C., and Prutzman, J.M., 1990. High resolution planktic stable isotope record and spectral analysis for the last 5.35 M.Y: Ocean Drilling Program Site 625, Northeast Gulf of Mexico. Paleoceanography, 5:507-529.

Katz, M.E., and Miller, K.G., 1991. Miocene to Pliocene subsidence of the Marion and Queensland Plateaus, N.E. Australian Margin: benthic foraminifera evidence. Geol. Soc. Am., 23:A337. (Abstract)

Keigwin, L.D., 1986. Pliocene stable-isotope record of Deep Sea Drilling Project Site 606: sequential events of ${ }^{18} \mathrm{O}$ enrichment beginning at $3.1 \mathrm{Ma}$. In Ruddiman, W.F., Kidd, R.B., Thomas, E., et al., Init. Repts. DSDP, 94 (Pt. 2): Washington (U.S. Govt. Printing Office), 911-920.

Kennett, J.P., 1982. Marine Geology: Englewood Cliffs, NJ (Prentice Hall).

Kohout, F.A., Henry, H.R., and Banks, J.E., 1977. Hydrogeology related to geothermal conditions of the Floridian Plateau. In Smith, K.L., and Griffen, G.M. (Eds.), The Geothermal Nature of the Floridian Plateau. Spec. Publ.-Fl., Dep. Nat. Resour. Bur. Geol., 21.

Krajewski, K.P., 1984. Early diagenetic phosphate cements in the Albian condensed glauconitic limestone of the Tatra Mountains, western Carpathians. Sedimentology, 31:443-470.
Kress, A.G., and Veeh, H.H., 1980. Geochemistry and radiometric ages of phosphatic nodules from the continental margin of northern New South Wales. Mar: Geol., 36:143-157.

Krom, M.D., and Berner, R.A., 1980. Adsorption of phosphate in anoxic marine sediments. Limnol. Oceanogr., 25:797-806. , 1981. The diagenesis of phosphorus in a nearshore marine sediment. Geochim. Cosmochim. Acta, 45:207-216.

Longman, M.W., 1980. Carbonate diagenetic textures from nearsurface diagenetic environments. AAPG Bull., 64:461-487.

Mayer, L.A., Shipley, T.H., Theyer, F., Wilkens, R.W., and Winterer, E.L., 1985. Seismic modelling and paleoceanography at DSDP Site 574. In Mayer, L.A., Theyer, F., Thomas, E., et al., Init. Repts. DSDP, 85: Washington (U.S. Govt. Printing Office), 947-970.

Mayer, L.A., Shipley, T.H., and Winterer, E.L., 1986. Equatorial Pacific seismic reflectors as indicators of global oceanographic events. Science, 233:761-764.

McClain, W.R., Freeman-Lynde, R.P., and Lohmann, K.C., 1988. Petrography and stable oxygen and carbon isotope compositions of Campanian grainstones and rudstones, Northeast Providence Channel, Bahamas: ODP Leg 101, Hole 634A. In Austin, J.A., Jr., Schlager, W., et al., Proc. ODP, Sci. Results, 101: College Station, TX (Ocean Drilling Program), 245-253.

Moore, T.C., Jr., Pisias, N.G., and Heath, G.R., 1977. Climate changes and lags in Pacific carbonate preservation, sea surface temperature and global ice volume. In Anderson, N.R., and Malahoff, A. (Eds.), The Fate of Fossil Fuel $\mathrm{CO}_{2}$ in the Oceans: New York (Plenum), 145-165.

Moore, T.C., Jr., van Andel, T.H., Sancetta, C., and Pisias, N., 1978. Cenozoic hiatuses in the pelagic sediments. Micropaleontology, 24:113-138.

Morse, J.W., and Mackenzie, F.T., 1990. Geochemistry of Sedimentary Carbonates: Amsterdam (Elsevier), Dev. in Sedimentol. Ser., 48.

Mullins, H.T., Wise, S.W., Jr., Gardulski, A.F., Hinchey, E.J., Masters, P.M., and Siegel, D.I., 1985. Shallow subsurface diagenesis of Pleistocene periplatform ooze: northern Bahamas. Sedimentology, 32:473-494.

O'Brien, G.W., Heggie, D.T., Skyring, G.W., Reimers, C.E., Moriarty, D.J., and Herczeg, A., 1988. Organic carbon cycling and the formation of modern marine phosphorites on the East Australian Continental Margin. Eos, 69:1234-1235.

Prell, W.L., 1985. Pliocene stable isotope and carbonate stratigraphy (Holes $572 \mathrm{C}$ and 573A): paleoceanographic data bearing on the question of Pliocene glaciation. In Mayer, L., and Theyer, F., Thomas, E., Init. Repts. DSDP, 85: Washington (U.S. Govt. Printing Office), 723-734.

Raymo, M.E., Ruddiman, W.F., Backman, J., Clement, B.M., and Martinson, D.G., 1989. Late Pliocene variation in Northern Hemisphere ice sheets and North Atlantic deep water circulation. Paleoceanography, 4:413-446.

Roa, C.P., 1981. Criteria for recognition of cold-water carbonate sedimentation: Berriedale Limestone (Lower Permian), Tasmania, Australia. J. Sediment. Petrol., 512:491-506.

Schaffer, G., 1986. Phosphate pumps and shuttles in the Black Sea. Nature, 321:515-517.

Schlager, W., and James, N.P., 1978. Low-magnesian calcite limestones forming at the deep-sea floor, Tongue of the Ocean, Bahamas. Sedimentology, 25:675-702

Schuffert, J.D., 1988. Multi-layered authigenic apatite formation off Southern Baja California. Eos, 69:1234.

Shackleton, N.J., and Hall, M.A., 1984. Oxygen and carbon isotope stratigraphy of Deep Sea Drilling Project Hole 552A: Plio-Pleistocene glacial history. In Roberts, D.G., Schnitker, D., et al., Init. Repts. DSDP, 81: Washington (U.S. Govt. Printing Office), 599-609.

Wilkinson, B.H., Smith, A.L., and Lohmann, K.C., 1985. Sparry calcite marine cement in Upper Jurassic limestones of southeastern Wyoming. Spec. Publ.-Soc. Econ. Paleontol. Mineral., 36:169-184.

Date of initial receipt: 1 July 1992

Date of acceptance: 22 January 1993

Ms 133SR-255 